\title{
Antimicrobial Activity, Phenolic and Antioxidant Content of Extracts from Cuajilote (Parmentiera aculeata Kunth) Fruits at Different Degrees of Ripening
}

Santiago Ruiz Cristina, Nuricumbo Lievano Viviana Noemi, Chapa Barrios Mariana Gabriela, Vela Gutiérrez Gilber, Velázquez López Arturo Alberto*.

Laboratorio de Investigación y Desarrollo de Productos Funcionales. Facultad de Ciencias de la Nutrición y Alimentos. Universidad de Ciencias y Artes de Chiapas. Libramiento Norte Poniente 1150. Ciudad Universitaria. Col. Lajas Maciel.

*Corresponding author: Velázquez López Arturo Alberto, email: arturo.velazquez@unicach.mx

Received July 19 ${ }^{\text {th }}$, 2020; Accepted December $14^{\text {th }}, 2020$.

DOI: http://dx.doi.org/10.29356/jmcs.v65i2.1270

\begin{abstract}
Antioxidants and phenolic compounds are involved in antioxidative processes, decreasing the activity of free radicals. Cuajilote (Parmentiera aculeata) is a crop of the state of Chiapas, Mexico, mainly used as feed for cattle, unknown the compounds that the fruit may contain, but many researches indicate that this fruit has been used for therapeutic purposes. Therefore, the purpose of the present study is the evaluation of the antioxidant, antibacterial and polyphenol content of pulp and seed of cuajilote. The recollected fruit were classified by degree of ripeness (green $(\mathrm{G})$, mature green ripe (MG) and ripe (R)). The samples were dry at $40{ }^{\circ} \mathrm{C}$. Aqueous, ethanol and methanolic extracts were obtained from degree of ripeness mentioned above. Higher antioxidant activity was obtained from ethanolic extracts of ripe pulp, greater polyphenol content from methanolic extracts from ripe pulp and antibacterial activity in ethanolic extracts from cuajilote pulp. The pulp has a higher antioxidant activity and polyphenol concentration in the ripe stage.
\end{abstract}

Keywords: Antioxidant; phenols; antibacterial; ripening; cuajilote.

Resumen. Los antioxidantes y compuestos fenólicos intervienen en los procesos antioxidantes, disminuyendo la actividad de los radicales libres. El Cuajilote (Parmentiera aculeata) es un cultivo del estado de Chiapas, México, utilizado principalmente como alimento para el ganado, desconociendo los compuestos que el fruto puede contener, pero muchas investigaciones indican que el fruto se ha utilizado para fines terapéuticos. Por lo tanto, el propósito del presente estudio es la evaluación del contenido antioxidante, antibacteriano y de polifenoles de la pulpa y la semilla de cuajilote. Los frutos recogidos se clasificaron por grado de maduración (verde $(\mathrm{G})$, maduro-verde-maduro (MG) y maduro (R)). Las muestras se secaron a $40{ }^{\circ} \mathrm{C}$, los extractos acuosos, etanólico y metanólico contuvieron los compuestos de interés. Se obtuvo actividad antioxidante mayor en los extractos etanólicos de pulpa madura; un mayor contenido de polifenoles a partir de extractos metanólicos de pulpa madura y elevada actividad antibacteriana en extractos etanólicos de la pulpa de cuajilote. La pulpa presenta superior actividad antioxidante y concentración de polifenoles en la etapa madura.

Palabras clave: Antioxidante; fenoles; antibacteriano; maduración; cuajilote. 


\section{Introduction}

Mexico has a great variety of native plants, among which is the cuajilote ( $P$. aculeata). The cuajilote fruits are mainly used as fodder for livestock [1], occasionally for human consumption [2], while the three is used as live fence and source of shade. P. aculeata is distributed in southern and central region of Mexico, generally in the states of Oaxaca, Tabasco, and Chiapas [3]. However, because it is a non-traditional crop, it is not intensively cultivated [2], which is why this crop does not present statistical data on its production. Different studies indicate that the cuajilote fruit contains a high percentage of crude fiber $(3,11$ to $4,25 \%$ ), which is beneficial for human nutrition [4-6].

Plants produce a wide variety of compounds such as alkaloids, glycosides, terpenoids, saponins, steroids, flavonoids, tannins, quinones and coumarins. These biomolecules are the main source of substances with antimicrobial activity, some of these natural products are highly efficient against bacteria that cause infections in humans $[7,8]$.

As a product of their secondary metabolism, plants are capable of biosynthesizing phenolic compounds, some of which are essential for their physiological functions and others are used for defending themselves against stress situations that can be produced by the climate or by animals [9]. Phenolic compounds have an aromatic nucleus that contains a free or substituted hydroxyl group and are differentiated from other compounds that also possess this phenolic structure as terpenes, due to their biosynthetic origin. Some of the phenolic compounds that are considered as active principles of medicinal plants originate through mixed routes that combine the shikimate and acetate pathways, as is the case of flavonoids, or that arise through combination of the mevalonate pathway, origin of the terpene compounds, with the shikimate pathway [10]. An antioxidant is a substance that can be found in food and can prevent the adverse effects of reactive oxygen species (ROS) [11] on normal physiological functions in humans [12]. Research on phytochemicals has emerged as a new opportunity to find new natural compounds for the treatment of degenerative diseases, or for obtaining new drugs, to improve their effectiveness and reduce their side effects [6]. Besides, depending on the state of maturation, the fruits develop a greater number of compounds, bioactives and antioxidant activity in turn the concentration of lipid profile $[13,14]$.

In the case of cuajilote fruit there is still no research regarding these compounds, but it is known that cuajilote is used for the treatment of asthma [15], as antidiuretic [16], laxative [17] and in the treatment of diabetes [3].

The cuajilote is popularly used in the treatment of Diabetes mellitus in various regions of the states of Veracruz, Tabasco, and Chiapas in Mexico. In Veracruz and Quintana Roo, the fruit is consumed parboiled, and is used for a variety of conditions such as headaches, gallstones, and diarrhea [18]. Therefore, the objective of this project is to evaluate the antioxidant, phenolic and antibacterial activity of aqueous and solvent extracts of cuajilote fruits at different stages of maturity.

\section{Experimental}

\section{Materials and Methods \\ Plant material and extract elaboration}

Cuajilote fruits were collected in communities of Chiapa de Corzo, Chiapas, Mexico during August 2019; three-degree ripeness were considered: green (G), mature green ripe (MG) and ripe (R); free of phytosanitary damages such as spots, pitting, deformations or any foreign material that could affect the process of fruit selection. These were placed in sealed wooden containers and labeled to avoid any mechanical damage that may occur during the transport period. This project was developed in the Laboratorio de Investigación y Desarrollo de Productos Funcionales (LIPDF), cuajilote fruits were disinfected in a solution of chloride 0,002 $\mathrm{M}$ for 10 minutes.

Previously the pulp and seed were dried at $60^{\circ} \mathrm{C}$ for 48 hours in a conventional drying oven (TERLAB, TE-FH45DM, China). Then pulp and seed dried ( $20 \mathrm{~g})$ were extracted with water, ethanol and methanol (1:10 w/v) for 48 hours, the extract was filtered using filter paper (grade number 4 ) and the solvent was evaporated 
under vacuum $\left(45^{\circ} \mathrm{C}\right)$. Obtained cuajilote pulp and seed extracts (A: water, E: ethanol, M: methanol) (Table 1) were stored at $4^{\circ} \mathrm{C}$ and in amber flasks until their use.

Table 1. Experiment design.

\begin{tabular}{|c|c|}
\hline Sample & $\mathbf{A}=$ water, $\mathbf{E}=$ Ethanol, $\mathbf{M}=$ Methanol \\
\hline \multirow{3}{*}{ Pulp } & Extracts A \\
\cline { 2 - 2 } & Extracts E \\
\cline { 2 - 2 } & Extracts M \\
\hline \multirow{3}{*}{ Seeds } & Extracts A \\
\cline { 2 - 2 } & Extracts E \\
\cline { 2 - 2 } & Extracts M \\
\hline
\end{tabular}

\section{Color measurements}

The external color of the fruit was measured with a colorimeter (KONICA® MINOLTA, CM-600d, Japan). For each measurements of color, three readings were performed of each of the fruits, thereby obtaining an average, Values $\mathrm{L}^{*}$, hue angle $\left({ }^{\circ}\right.$ hue) and chroma (C) was measured (CIELab).

\section{Determination of antioxidant capacity}

Because the cuajilote is not a common fruit was decided to measure changes color, the total antioxidant capacities of cuajilote pulp and seeds were analyzed by ABTS radical scavenging assays (ABTS method) [19]. The $\mathrm{ABTS}^{-+}$stock solution was produced by reacting ABTS (Sigma $\left.{ }^{\circledR}\right)$ aqueous solution $(7 \mathrm{mM})$ with $2.45 \mathrm{mM}$ aqueous solution of potassium persulfate (J.T. Baker®) in equal volumes, allowed them to react for $24 \mathrm{~h}$ at room temperature in the dark. Then, $1 \mathrm{~mL}$ of ABTS $^{-}$solution was mixed with $0.5 \mathrm{ml}$ of the pulp or seed extracts or standard solution. The mixture was incubated at room temperature for exactly 10 minutes in the dark and the absorbance was acquired at $734 \mathrm{~nm}$ using a spectrophotometer (VELAB, VE-51000a, Mexico). Previously a standard curve was made with TROLOX (Sigma ${ }^{\circledR}$ ) at different concentrations (10 to $100 \mu \mathrm{M}$ ), the control was prepared by mixing $1 \mathrm{~mL}$ of ABTS* solution with $0,5 \mathrm{ml}$ of distilled water.

\section{Total phenolic content}

The polyphenols concentration was quantified by Folin-Ciocalteu method [20]. $250 \mu \mathrm{L}$ of the supernatant from the aqueous, ethanol and methanol extracts were taken and placed in $25 \mathrm{~mL}$ volumetric flasks; subsequently, $15 \mathrm{~mL}$ of deionized distilled water and $1,25 \mathrm{~mL}$ of Folin reagent (Sigma $\left.{ }^{\circledR}\right)$ were added, the mixture was incubated in darkness for 1 hour. The absorbance was determined at $765 \mathrm{~nm}$ and results were reported as milligram of gallic acid equivalents (GAE)/g d. w. Previously, a standard curve was made with gallic acid at different concentrations (0 to $3.0 \mathrm{mg} / \mathrm{mL})$.

\section{Antibacterial activity}

The antibacterial activity was quantified by disc-diffusion assay [21]. The Gram-negative bacteria, Salmonella enterica serotype Typhi, was cultured on nutrient agar at $37^{\circ} \mathrm{C}$ for $24 \mathrm{~h}$, after $6 \mathrm{~h}$ of growth, the bacteria, at a concentration of $>10^{6} \mathrm{CFU} / \mathrm{mL}$, was inoculated on the surface of Mueller-Hinton agar plates. Then, filter paper discs $(5 \mathrm{~mm}$ in diameter) saturated either with extracts were placed on surface of each inoculated plate. The plates were incubated at $37^{\circ} \mathrm{C}$ for $24 \mathrm{~h}$, after it was possible to observe inhibition zone. Overall, cultured bacteria with halos equal or greater than $5 \mathrm{~mm}$ were considered susceptible to either tested extracts. The control were the solvents used for each extract. Antibacterial activity was expressed as the zone of inhibition $(\mathrm{mm})$ produced by the extract compared with the positive controls (the solvents used for each extract) and negative control (amoxicillin). 


\section{Statistical analysis}

All the experiments were executed in triplicated. The data were expressed as the mean \pm standard deviation (SD) an analyzed trough ANOVA by using MINITAB® 17.1.0 for AMD. The differences between groups were considered statistically significant at $\mathrm{p}<0,05$.

\section{Results and discussion}

In the present study, we used CIE-Lab method to describe the color development of cuajilote fruits, because there is no research on this evaluation. We quantify the parameters $\mathrm{L}, \mathrm{a} *, \mathrm{~b} *$ to show the color changes in the peel fruit.

Using the method described above, the color development in the cuajilote ripening process was analyzed. Table 2 shows the results for the parameters $\mathrm{L}, \mathrm{a}^{*}, \mathrm{~b}^{*}$ of cuajilote peel. As shown, the results for the luminosity did not present a significant difference in the three-degree ripeness, ranging from 60,04 to 57,91, with a slow decrease in values; parameter $\mathrm{a}^{*}$ showed significant difference in the $\mathrm{R}$ stage. The development of color in the skin of the cuajilote occurs from intense green to light yellow.

Table 2 gives the result of color from cuajilote peel, the difference observed according to Martínez et al. [22] is because pigments commonly accumulated in the skin during the ripening process, although many climacteric fruits also accumulate pigments in the pulp tissue during postharvest ripening, unlike nonclimacteric fruits. However, because of their role in coloration, they are important for human health as sources of vitamin A and antioxidant compounds [23]. In addition, the luminity values (Table 2) indicate that the cuajilote is a non-climacteric fruit because there is no present difference, as in a climacteric fruit with visible color changes [24] because climacteric fruits show autocatalytic ethylene production result in color changes in the ripening process [25].

Table 2. Coordinates $\mathrm{L}, \mathrm{a} *, \mathrm{~b} *$ in three-degree ripeness.

\begin{tabular}{|c|c|c|c|}
\hline Colour & $\mathbf{G}$ & $\mathbf{M G}$ & $\mathbf{R}$ \\
\hline $\mathbf{L}$ & $60,04^{\mathrm{a}}$ & $59,57^{\mathrm{a}}$ & $57,91^{\mathrm{a}}$ \\
\hline $\mathbf{a}^{*}$ & $14,28^{\mathrm{b}}$ & $5,53^{\mathrm{b}}$ & $1,86^{\mathrm{c}}$ \\
\hline $\mathbf{b}^{*}$ & $37,77^{\mathrm{d}}$ & $35,36^{\mathrm{d}}$ & $35,36^{\mathrm{d}}$ \\
\hline
\end{tabular}

*Different letters indicate significant difference between treatments $(\mathrm{p}<0.05$, ANOVA).

Fig. 1(a) shows the results of the behavior of the hue angle $\left({ }^{\circ} h\right)$ during the ripening of the cuajilote fruit, observing an increase in their values; in stage $\mathrm{G}$ has a greenish color $(71,47)$, in $\mathrm{R}$ changes to yellowish green $(87,01)$. The results of ${ }^{\circ} \mathrm{h}$ and chroma in stage $\mathrm{G}$ show significant difference $(\mathrm{p}<0,05)$, because in this state it has a green coloration $\left({ }^{\circ} h=71,47\right)$ and a high intensity $($ chroma $=40,62)$ unlike the other states that present higher values of ${ }^{\circ} h$ and chroma. This difference between the results of ${ }^{\circ} h$ and chroma is due to the high concentration of chlorophyll in the skin of the fruit in the early stages of ripening, and the subsequent changes are due to the development of pigments such as anthocyanins, beta-carotene, among others (26). In the stages MG and R did not present significant differences ( $p>0,05)$. Similar results were obtained by Rao [11], in plum fruits, observing differences $(\mathrm{p}<0,05)$ in the values of ${ }^{o} h$ in three ripeness stages, while in chroma values did not present significant difference. 


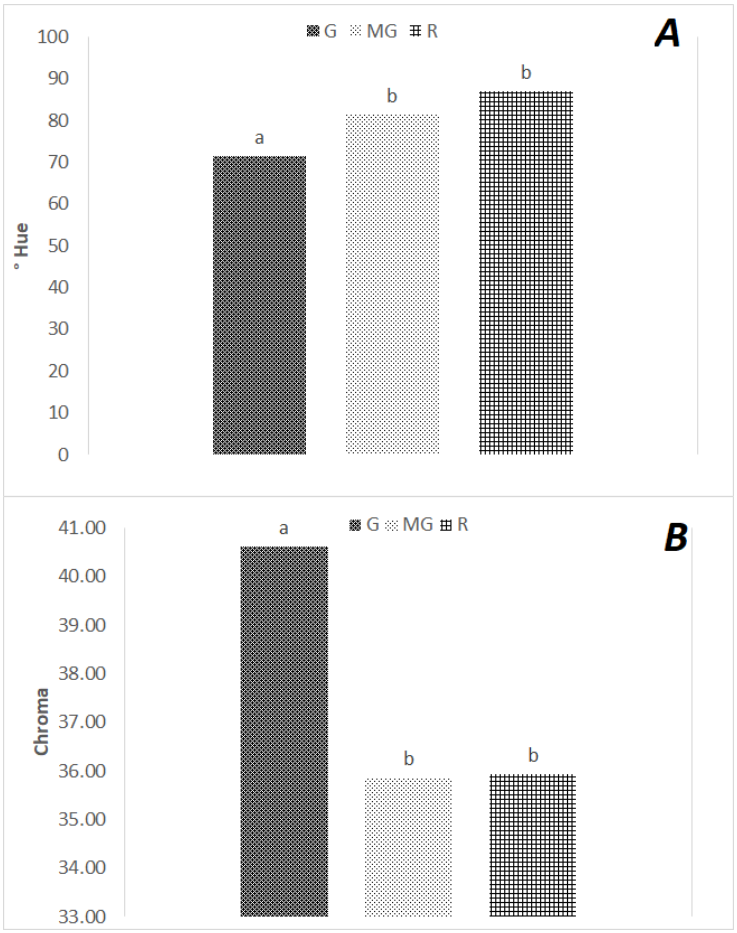

Fig 1. Changes of the angle hue (A) and Chroma (B) of cuajilote. *Different letters indicate significant difference between treatments ( $\mathrm{p}<0.05$, ANOVA).

In order to evaluate the properties of Parmentiera aculeata, trials were carried out with pulp and seed extracts. In the literature review, no reports on the content of secondary metabolites such as antioxidants and polyphenols were found, so the content of these was assessed. Aqueous, ethanolic and methanolic extracts (Table 3) showed different antioxidant activities, in seeds and pulp. The aqueous seeds extracts, in G stage, they showed higher antioxidant activity than in the MG and R stages; with respect to the ethanol extracts, the highest antioxidant activity was shown in the MG stage, and in the methanolic seed extracts the highest activity was presented in the R stage. On the other hand, the highest antioxidant activity of the aqueous pulp extracts was in the MG stage, for the ethanolic extracts it was in the MG and R stage (no significant difference) and for methanolic extracts in the $\mathrm{G}$ stage.

Table 3. Quantity of antioxidants in three ripening stages of the cuajilote with different extracts.

\begin{tabular}{|l|c|c|c|}
\hline \multicolumn{1}{|c|}{ Sample } & $\mathbf{G}(\mathbf{m g} / \mathbf{m L})$ & $\mathbf{M G}(\mathbf{m g} / \mathbf{m L})$ & $\mathbf{R}(\mathbf{m g} / \mathbf{m L})$ \\
\hline Seed (aqueous) & $0,283^{\mathrm{a}}$ & $0,127^{\mathrm{b}}$ & $0,161^{\mathrm{c}}$ \\
\hline Seed (ethanol) & $1,353^{\mathrm{a}}$ & $2,231^{\mathrm{b}}$ & $0,301^{\mathrm{c}}$ \\
\hline Seed (methanol) & $0,108^{\mathrm{a}}$ & $0,080^{\mathrm{b}}$ & $0,290^{\mathrm{c}}$ \\
\hline Pulp (aqueous) & $0,093^{\mathrm{a}}$ & $0,259^{\mathrm{b}}$ & $0,301^{\mathrm{c}}$ \\
\hline Pulp (ethanol) & $0,087^{\mathrm{a}}$ & $0,301^{\mathrm{b}}$ & $0,301^{\mathrm{b}}$ \\
\hline Pulp (methanol) & $0,374^{\mathrm{a}}$ & $0,150^{\mathrm{b}}$ & $0,301^{\mathrm{c}}$ \\
\hline
\end{tabular}

*Different letters indicate significant difference between treatments $(\mathrm{p}<0.05$, ANOVA).

In Table 4, the results of the polyphenol content of the analyzed extracts are presented. In seed, a high concentration of polyphenols is observed in the ethanolic extracts $(>2 \mathrm{mg} / \mathrm{mL})$, no significant difference $(p>0,05)$ in the ripening degrees analyzed. Furthermore, in whole analyzed seed extracts, the highest 
concentration of polyphenols is found in the $\mathrm{R}$ stage. On the other hand, in the pulp analyzes, the aqueous extract obtained a higher concentration in the MG and G stage, while in the ethanolic extracts was no significant differences, and methanolic extracts it is presented in the R stage, $2,92 \mathrm{mg} / \mathrm{mL}$. In both seed and pulp, the extracts that obtained the highest concentration of polyphenols were made with methanol when the cuajilote in stage R. The seed extract that presented greater antioxidant activity was obtained with ethanol, while the pulp extract had the highest activity, those obtained with methanol; due to the use of different solvents, the extraction of multiple active compounds with different intensities that can be reflected in different biological properties is allowed [27]. A higher antioxidant activity was obtained from stage three $(R)$ fruits extracts; these differences are due to the antioxidant activity of many fruits depending on the ripening stage, since the ripening process is related to the chemical and nutritional content of the fruits [10], as presented in tomato, which has been the study model $[4 ; 28]$.

Table 4. Polyphenols in three stage ripening of Cuajilote with different extracts.

\begin{tabular}{|l|c|c|c|}
\hline \multicolumn{1}{|c|}{ Sample } & $\mathbf{G}(\mathbf{m g} / \mathbf{m L})$ & MG $(\mathbf{m g} / \mathbf{m L})$ & R (ripe) $(\mathbf{m g} / \mathbf{m L})$ \\
\hline Seed (aqueous) & $1,36^{\mathrm{b}}$ & $1,52^{\mathrm{a}}$ & 1,98 \\
\hline Seed (ethanol) & $2,14^{\mathrm{a}}$ & $2,46^{\mathrm{a}}$ & $2,72^{\mathrm{a}}$ \\
\hline Seed (methanol) & $2,18^{\mathrm{a}}$ & $2,51^{\mathrm{b}}$ & $2,37^{\mathrm{c}}$ \\
\hline Pulp (aqueous) & $2,12^{\mathrm{a}}$ & $1,63^{\mathrm{b}}$ & $1,42^{\mathrm{b}}$ \\
\hline Pulp (ethanol) & $1,92^{\mathrm{a}}$ & $2,22^{\mathrm{a}}$ & $2,83^{\mathrm{a}}$ \\
\hline Pulp (methanol) & $2,41^{\mathrm{a}}$ & $2,25^{\mathrm{a}}$ & $2,92^{\mathrm{c}}$ \\
\hline
\end{tabular}

*Different letters indicate significant difference between treatments ( $\mathrm{p}<0.05$, ANOVA).

The methanolic extracts of pulp, according to Martínez et al. [29], present an immune response, cellular communication in vivo and antimutagenic that contributes to reduce the risks of the development of some diseases and prevention of different types of cancer. In peach fruit, the participation of anthocyanins in the total antioxidant capacity of the fruit is higher than the participation of the carotenoids [30]. In addition, the activity of carotenoids involves the inactivation of reactive oxygen species, while the function of anthocyanins is related to a protection against oxidative damage. Also, the extraction of polyphenols is related to the affinity for the solvent [31-33]. It is demonstrated that very active extracts with high phenolic content can be obtained from ethanol; these results are concordant with those obtained by Nossa [28], who determined the content of antioxidants and polyphenols in the leaves where ethanolic extracts show higher content of polyphenols.

Polyphenols are one of the most numerous and widely distributed groups in plants, with more than eight thousand phenolic structures currently known. In the human diet the common phenolic compounds are phenolic acids, flavonoids and tannins [34], most of them are highly polar, water-soluble; however, their extraction can have disadvantages such as the co-extraction of other water-soluble compounds difficult to separate, such as sugars, peptides or enzymes, therefore, extractions with methanol and ethanol are made to avoid the presence of associated compounds that can produce changes in the molecule originally present [35].

The results in table 3 are due to the content of polyphenols present in plant foods, which is related to the flavonoids that are associated with the colors imparted by the pigments present in fruits, vegetables, cereals, grains and seeds; flavonols, flavones, calcones and flavonones are responsible for the colors, smell and flavors of food, which also contain the ability to inhibit free radicals [36].

These results are similar to those reported in a study of carambola that has three stages of maturity (dark green, light green and yellow), each stage having a different concentration of polyphenols; in phytochemical studies carried out, phenolic compounds, proanthocyanidinic flavonoids and tannins have been identified within the fruit, which undergo changes with the ripening process [37]; however, our data (Tables 3 and 4) are lower compared to some fruits such as pineapple, guava, soursop (Annona muricata) [25], papaya [38] and mango [39]. In comparison with the polyphenols values of other fruits studied, such is the case of the tuna, which has a value of 2,463 mg/mL [40], custard apple (Annona squamosa L.) 1,443 [41] and carambola a value of 1,074 [37]; comparing the values there is a similarity in the same percentage range of polyphenols as our study model [42]. 
The antibacterial activity (Table 5) was performed against Salmonella typhi, a bacterium that produces infectious diseases and is known to be present in food. The positive controls (solvent) showed no inhibition, and the negative control (amoxicillin) showed an inhibition diameter of $17 \pm 0.22 \mathrm{~mm}$. Little inhibition of the bacteria was observed with the seed extracts; obtaining greater antibacterial activity in the ethanolic extracts in the R stage $(2 \mathrm{~mm})$. In pulp, the methanolic extract showed greater antibacterial activity during the MG stage $(3,3 \mathrm{~mm})$. In addition, in seed and pulp, the aqueous extracts showed the least antibacterial activity $(<2 \mathrm{~mm})$ in all the ripening stages analyzed.

Table 5. Antibacterial activity of cuajilote seed and pulp extracts.

\begin{tabular}{|l|c|c|c|}
\hline \multicolumn{1}{|c|}{ Sample } & $\mathbf{G}(\mathbf{m m})$ & $\mathbf{M G}(\mathbf{m m})$ & $\mathbf{R}(\mathbf{m m})$ \\
\hline Seed (aqueous) & $0^{\mathrm{a}}$ & $1,7^{\mathrm{b}}$ & $1^{\mathrm{b}}$ \\
\hline Seed (ethanol) & $1^{\mathrm{b}}$ & $1,7^{\mathrm{b}}$ & $2,0^{\mathrm{b}}$ \\
\hline Seed (methanol) & $1^{\mathrm{b}}$ & $1^{\mathrm{b}}$ & $1,1^{\mathrm{b}}$ \\
\hline Pulp (aqueous) & $1^{\mathrm{b}}$ & $1,3^{\mathrm{b}}$ & $0,6^{\mathrm{b}}$ \\
\hline Pulp (ethanol) & $1,2^{\mathrm{b}}$ & $1,0^{\mathrm{b}}$ & $1,7^{\mathrm{b}}$ \\
\hline Pulp (methanol) & $1,7^{\mathrm{b}}$ & $3,3^{\mathrm{c}}$ & $2,7^{\mathrm{c}}$ \\
\hline
\end{tabular}

*Different letters indicate significant difference between treatments $(\mathrm{p}<0.05$, ANOVA).

According to the results obtained, the pulp extracts have a greater antibacterial effect by inhibiting the growth of Salmonella typhi $(1$ to $3 \mathrm{~mm})$. The extracts that produce the greatest antagonistic effect are those of ripe pulp, specifically the extracts with ethanol. This result is related to those obtained previously because high concentrations of antioxidants and polyphenols were obtained in the ripened pulp; during the ripening process plants generally develop certain compounds that contain antagonistic activities against fungi or bacteria so that these plants can survive and develop normally. One of the most studied compounds is jasmonic acid, which is related to the defense of plants against pathogens, as well as possibly due to the terpene content of these pods [43].

The antibacterial results of the cuajilote extract are related to the presence of antioxidants and polyphenols, as well as other bioactive compounds that can be produced by plants in general. The methanol extract from pulp (MG) obtained 3,3 mm of inhibition halo, possibly due to the fact that some essential oils were extracted with the use of this solvent. Some oils have been known to have antibacterial activity; such is the case of limonene from lemon skins obtained with methanol extracts [44].

\section{Conclusion}

The pulp and seed of cuajilote (Parmentiera aculeata) show antioxidant and phenolic activity, being the pulp the one that shows more activity. All the extracts show little antibacterial activity compared to other investigations that report inhibition halos between 10 to $15 \mathrm{~mm}$ [45; 5], highlighting the mature pulp methanol extracts.

The concentration of antioxidants and polyphenols in cuajilote fruit does not depend on the ripening stage in which it is found but highlighting the ripening stage where more coloration was observed as well as a more antibacterial activity. Cuajilote contains adequate amounts of antioxidants and polyphenols for health, although it depends on the stage of maturation. Cuajilote has adequate amounts of bioactive compounds for human consumption. 


\section{Acknowledgements}

Acknowledgments to the University of Sciences and Arts of Chiapas for providing us with the facilities in the development of this project.

\section{References}

1. Morales-Sánchez, V.; Osuna-Hernández, H.R.; Brechú-Franco, A.; Laguna-Hernández, G; VargasSolís, R. Bot. Sci. 2015, 93, 293-298.

2. García, C.; Martinez, J.; Montañes O.; Sanchez, L; Posada, S.; Izaguirre, F.; Martinez, G. Trop. Zootech. 2008, 26, 1-8.

3. Escamilla, B.; Moreno, P. Medicinal plants. 1st ed. Institute of Ecology Veracruz Mexico. Instituto Literario de Veracruz, S.C. 2015.

4. Abushita, A.A.; Daood, H.G.; Biacs, P.A. J. Agr. Food Chem. 2000, 48, 2075-2081 DOI: https://doi.org/10.1021/jf990715p.

5. Akinyemi, K.; Oluwa, O.; Omomigbehin, O. Afr. J Tradit. Complem. 2006, 38, 13-22 DOI: https://doi.org/10.4314/ajtcam.v3i4.31173.

6. Estanislao, C.; Ordaz, C.; Martín, E.; Pérez, N.; Pérez, G.; Gómez, C. J. Appl. Pharm. Sci. 2016, 6, 1522 DOI: https://doi.org/10.7324/JAPS.2016.600103.

7. Ayman, A.; Mazen. Iran. J. Med. Sci. 2014, 39, 36-43.

8. Ishaku, L.; Francien, B.; Lyndy, J.; Jacobus, . BMC Complem. Altern. M. 2017, 17, 1-10 DOI: https://doi.org/10.1186/s12906-017-1645-z.

9. Sujin, A.; Misung, E.; Taesum, S.; Nam, K.; Hyeung, R. Food Chem. 2018, 278, 178-184 DOI: https://doi.org/10.1016/j.foodchem.2018.11.058.

10. Cabrera, M.; Salinas, Y.; Velázquez, G. Agro-science. 2009, 43, 827-839.

11. Rao, S.; Santhakumar, A.; Chinkwo, K.; Wu, G.; Johnson, S.; Blanchard, C. J. Cereal Sci. 2018, 84, 103-111 DOI: https://doi.org/10.1016/j.jcs.2018.07.013

12. Coronado, M.; Vega, S.; Gutiérrez, R.; Vázquez, M.; Radilla, C. J. Chil. Nutr. 2015, 42 (2), $206-212$ DOI: http://dx.doi.org/10.4067/S0717-75182015000200014.

13. Ilahy, R.; Hdider, C.; Lenucci, M. S.; Tlili, I.; Dalessandro, G. J. Food Compos. Anal. 2011, 24, 588595 DOI: https://doi.org/10.1016/j.jfca.2010.11.003.

14. Rodríguez, J. C.; Gómez, D.; Pacetti, D.; Núñez, O.; Gagliardi, R.; Frega, N.G.; Lucci, P. J. Agr. Food Chem. 2016, 64, 852-859 DOI: https://doi.org/10.1021/acs.jafc.5b04990.

15. Weizel, S.; Waizel, J. AN ORL MEX. 2009, 54, 145-171.

16. Morales, M.; Osuna, H.; Brechú, A.; Laguna, G.; Vargas, R. Bot. Sci. 2015, 93, 293-295.

17. http://www.medicinatradicionalmexicana.unam.mx, accessed in December 2020.

18. Pérez-Gutiérrez, R.; Pérez-González, C.; Zavala-Sánchez, M.; Pérez-Gutiérrez, S. Salud Publ Mex. 1998, 40, 354-358 DOI: https://doi.org/10.1590/s0036-36341998000400008.

19. Mareček, V.; Mikyška, A.; Hampel, D.; Čejka, P.; Neuwirthová, J.; Malachová, A.; Cerkal, R. J. Cereal Sci. 2017, 73, 40-45. Doi: http://dx.doi.org/10.1016/j.jcs.2016.11.004.

20. Eghdami, A; Sadeghi, F.Org. Chem.2010, 2, 81-84.

21. Hussain, T.; Arshad, M.; Khan, S.; Sattar, H.; Subhan, M. Pak.J. Bot. 2011, 43, 531-538.

22. Martínez, M.E.; Balois, R.; Alia, I.; Cortes, M.; Palomino, Y.; López, G. Mex. J. Agric. Sci. 2017, 19, 4075-4087 DOI: http://dx.doi.org/10.29312/remexca.v0i19.674. 
23. African, K.; Almanza, P.; Balaguera, H. Rev. Colomb. Cienc. Hortic. 2015, 9, 161-172 DOI: http://dx.doi.org/10.17584/rcch.2015v9i1.3754.

24. Radzevičius, A.; Viškelis, P.; Viškelis, J.; Karklelienė, R.; Juškevičienė, D. International Journal of Biological, Biomolecular, Agricultural, Food and Biotechnological Engineering. 2014, 8, 112-114.

25. Ramirez, A.; Pacheco, E. Intersciousnes. 2011, 36, 71-76.

26. Cox, K.; McGhie, T.; White, A.; Woolf, A. Postharvest Biol. Tec. 2003. 31, 287 - 294.

27. Roslie, R.; Joas, J.; Deyteieux, C.; Vulcain, E.; Payet, B.; Dufossé, L.; Léchaudel, M. J. Plant. Physiol. 2015, 184, 68-78 DOI: https://doi.org/10.1016/j.jplph.2015.05.019.

28. Nossa, D.; Talero, Y.; Rozo, W. RCMP. 2016, 21 (2), 22-30.

29. Martínez, V.M.; Aristizábal, I.; Moreno, E. J. Faculty of Pharmaceutical and Food Sciences. 2017, 24, 47-58 DOI: http://dx.doi.org/10.17533/udea.vitae.v24n1a06.

30.Zhao, X.; Zhang, Q.; Yin, X.; Su, M.; Sun, C.; Li, X.; Chen, K. Int. J. Mol. Sci. 2015, 16, 5762-5778 DOI: https://doi.org/10.3390/ijms16035762.

31. Igarza, O.; Abreu, L.; Cordero, E.; Pérez. Forestry magazine Baracoa. 2006, 25, 65-76 DOI: https://doi.org/10.1007/s00226-011-0418-y.

32. Muñoz, W.; Chavez, W.; Pabón, L.; Rendón, M.; Patricia, M.; Otálvaro, A. CENIC Magazine. 2015, 46, 38-46 DOI: https://doi.org/10.2174/1573401313666170609102336.

33. Sepúlveda, C.; Ciro, G.; Zapata, J. RCPM. 2016, 21, 133-144.

34. Pereira, G.; Vianello, F.; Renata, C.; Campos, R.; Borguini, M. Food Sci. Nutr. 2014, 5, $1065-1082$ DOI: https://doi.org/10.4236/fns.2014.511117.

35. Dwivedi, J.; Singh, M.; Sharma, S.; Sharma, S. J. Herbs. Spices Med. Plants. 2017, 23, 363-377. DOI: https://doi.org/10.1080/10496475.2017.1345029.

36. Ozca, T.; Akpinar, A.; Tilma, L.; Delikanli, B. Int. J. Chem. Eng. 2014, 5, 393-397 DOI: https://doi.org/10.7763/IJCEA.2014.V5.416

37. Muñoz, A.; Ramos, F.; Alvarado, C.; Castañeda, B.; Lizaraso, F. Rev. Soc. Quim. Peru. 2009. 75, 431438.

38. Vuong, Q.V.; Hirun, S.; Roach, P.D.; Bowyer, M.C.; Phillips, P.A.; Scarlett, C.J. J. Herbs. Spices Med. Plants. 2013, 3, 104-111 DOI: https://doi.org/10.1016/j.hermed.2013.04.004.

39. Nemec, M.J.; Kim, H.; Marciante, A.B.; Barnes, R.C.; Hendrick, ED.; Bisson, W.H.; Stephen, T.; Susanne, U.; Mertens, S.U. J. Nutr. Biochem. 2016, 41, 12-19 DOI: https://doi.org/10.1016/j.jnutbio.2016.11.005.

40. Luzmilla, P. Annual Faculty of Medicine. 2016, 77, 105-109 DOI: http://dx.doi.org/10.15381/anales.v77i2.11812.

41. Vit, P.; Santiago, B.; Pérez, E. Interciencia. 2014, 39, 350-353.

42. Padalia, H.; Poptani, R.; Chanda, S. J. Herbs. Spices Med. Plants. 2017, 24, $15-27$ DOI: https://doi.org/10.1080/10496475.2017.1357159.

43. Laredo, E.; Martínez, J.; Guillen, L.; Castillo, F. REMEXCA. 2017, 8, 673-683.

44. Torrenegra, M.; Pájaro, N.; León, G. Rev. Colomb. Cienc. Quim. Farm. 2017, 46, 160-175.

45. Gislene, G.; Nascimento, F.; Locatelli, J.; Freitas, P.; Silva, G. Braz. J. Microbiol. 2000, 321, $27-256$

DOI: http://dx.doi.org/10.1590/S1517-83822000000400003. 